\title{
Measurement of Technical Efficiency of Irrigated and Rainfed Onion Farms in Kano State of Nigeria
}

\author{
Omolehin. R. A. \\ Department of Agricultural Economics and Extension, Federal University, Oye Ekiti, Nigeria \\ Muhammed Lawal \\ Department of Agricultural Economics, University of Ilorin, Nigeria \\ Coker Alexander Ayodeji \\ Department of Agricultural Economics, Federal University of Technology, Minna, Nigeria \\ Oyewole. S. O \\ Forestry Research Institute of Nigeria, Ibadan, Nigeria
}

\begin{abstract}
This study estimated technical efficiency of irrigated and rain-fed onion production in Kano State of Nigeria, and was carried out in six selected Local Government Areas (LGAs) of the state. A multi-stage sampling technique was used to select 217 onion farmers involved in both irrigated and Rain-fed production systems. The study made use of primary data, collected through structured questionnaires. Descriptive statistics and stochastic frontier model were used to analyse the data. Generally, young literate married men with 5 household size and14 years of farming experience were involved in onion farming. The Maximum Likelihood Estimate (MLE) for production frontier shows that the variable inputs (farm size, hired and family labour, seeds and fertilizers) have positive coefficients and were significant at 5\% level. This implied positive effect on onion yields under both production systems, while agro-chemical was negative under rain-fed. The mean technical efficiency was higher for irrigated onion farmers than rain-fed farmers indicating that onion production was technically more efficient under irrigation system of production than rain-fed system of production. Educations, experience, membership of cooperative, access to credit are socio-economic variables that reduce technical inefficiency in both systems of production. The following recommendations were made; contract farming, introduction of hybrid seeds, formation of cooperative societies and private partnership participation with government should be encouraged to boost irrigated onion production not only for home and local industry but also for export to other countries of the world.
\end{abstract}

Keywords: Technical efficiency, irrigated, rain-fed, onion production

DOI: $10.7176 /$ JRDM/54-02

Publication date: April $30^{\text {th }} 2019$

\section{Introduction}

Onion (Allium cepa) is one of the most important vegetables in the world, whose utility is ranked second to tomatoes (Brice, Currah, Malins and Bancroft 1999). According to Purseglove (2001), onion can be grown on a wide range of climatic conditions, but thrives best at mild climate without excessive rainfall or extremes of heat and cold. It requires a land with optimum soil $\mathrm{pH}$ of 6.0-7.0 with good tilth and high moisture content. It is a thermo and photosensitive crop, hence, the production of bulbs in onion is controlled by photoperiod, though temperature has marked influence. Onion production is a viable industry that employs plenty of labour and the bulbs are traded in large quantities within and between countries of the world (Currah and Proctor, 2000). Despite the ranking of onion as the second most important vegetable in Nigeria, the present production levels of 621,000 tones per year do not meet the demand of the teeming populace. Strict adherence to the traditional production practices may still be a major factor responsible for the inability to meet the national demand (Denton and Ojeifo, 2001). Though, the consumption of onion cuts across the country, its production is limited to the northern part of the country, where even in the north, production is restricted to fadama areas, and grown mostly during the dry season under irrigation because of the availability of water source and long day light. Similarly, the yield level at present is below the optimum realized for other countries, for example, while it is $45 \mathrm{t}$ ha- 1 in India, $57 \mathrm{t}$ ha-1 in China, it is just $15 \mathrm{t}$ ha-1 in Nigeria (FAO, 2005).

One of the main reasons for low productivity in crop production all over the world is the inability of farmers to fully exploit the available technologies, resulting in lower efficiencies of production. This fact has been emphasized in many studies, (Battese, 2001; Villano and Fleming, 2006; Mehmet and Ceyhan, 2007). Production in agriculture does not only depend on the resource utilization but the combinations of different inputs have a great contribution to total productivity. The differences across farms in the use of various factors of production and various combinations of factors of production cause the changes in crop yields. These 
combinations are considered as technology. The input use level and its combinations are different across farms resulting in different yields.

The question of efficiency in resource allocation in traditional agriculture is not trivial. It is widely held that efficiency is at the heart of agricultural production. This is because the scope of agricultural production can be expanded and sustained by farmers through efficient use of resources (Udoh, 2000). For these reasons, efficiency has remained an important subject of empirical investigation particularly in developing economies where majority of the farmers are resource-poor, and are being threatened by global warming. Okeowo (2011) has observed that farmer efficiency in vegetable crop production in Nigeria where resources are meagre and opportunities for developing and adopting better technologies have been on the decline. If this is the case, then empirical measures of efficiency are necessary in order to determine the magnitude of the gains that could be obtained by improving performance in onion production with a given mix of technology. An important policy implication stemming from significant levels of inefficiency is that it might be more cost effective to achieve short-run increases in farm output, and thus income, by concentrating on improving efficiency rather than on the introduction of new technologies (Belbase and Grabowski 2000; Shapiro and Müller 1999).

The essence of this study is to provide adequate information on the existing gap between irrigated and rainfed production systems to enable investors and policy makers take corrective decisions and policy formulation on onion production in Nigeria. Specifically, the study examined the socio-economic characteristics of irrigated and rain-fed onion farmers in the study area, estimate the level of technical efficiency for rain-fed and irrigated onion production, and identify the determinants of technical efficiencies of rain-fed and irrigated onion production.

\section{Methodology}

\subsection{Study area}

This study was conducted in Kano State of Nigeria, located between Latitude $10^{\circ} 35^{\prime}$ and $13^{0} 02^{\prime}$ north and between Longitude $7^{0} 30^{\prime}$ and $10^{\circ} 35^{\prime}$ east (Figure 1). It is bordered by Katsina State to the north-west, Jigawa State to the north-east, Bauchi State to the south-east and Kaduna State to the south-west (Figure 1). Kano State is with a total land area of 20,131 square kilometres and lies within the Sudano-Sahelian zone of Nigeria (Olofin et al., 2008). Kano State has a population of 9,383,682 with 470 person/ $\mathrm{Km}^{2}$ density (National Population Commission NPC, 2006). The estimated population in 2014 was 11.5 million at $2.5 \%$ annual increase.

Kano State is a commercial and agricultural centre and is known to be involved in vegetable crop production. The State has 18,684 square kilometres of cultivable land and with well over 3 million hectares of cultivable land under irrigation (Olofin et al., 2008). There were 120 earth dams in the State, majority of which are located in Kano territory. Today, the dams which include Challawa Gorge and Tiga Dam, two of the most gigantic irrigation projects in West Africa located in the state, ensure all year round farming.

The cropping system in the study area is mostly undertaken under the rainfed and irrigated conditions and majority of farmers are small-scale holders who grow their crops solely or in mixture with less than 2.5 ha/farming household and their resources are meager. The upland crops commonly grown are millet, sorghum, groundnut, cowpea and maize, while the low land Fadama crops grown in the State include tomato, onions, pepper and other vegetable with rice and wheat grown in irrigated dam areas.

\subsection{Sampling Procedure and Sample Selection}

A multi-stage sampling technique was used to select onion farmers for the study in order to capture variability in onion production. Firstly, random sampling technique was used to select six Local Government Areas from the twelve LGAs that are into both irrigated and rain-fed onion production. Secondly, four villages were purposively selected from each of the six LGAs, thereby giving a total of twenty four (24) villages for the study. The villages were so purposively selected based on the large concentration of both irrigated and rain-fed onion farmers in each of the villages selected for the study. Thirdly, $10 \%$ of the population were used as the basis for the selection of both irrigated and rain-fed onion farmers from each village designated for the study, thus giving a sample size of 217 onion farmers (106 irrigated and 111 rain-fed onion farmers) for the study.

\subsection{Methods of Data Collection}

The study used primary data, and this was collected with the aid of structured questionnaire. Additional information was also collected through oral interview from participating onion farmers. Information was equally collected on the socio-economic characteristics of onion farmers. This include age of farmers, level of education, family size, farming experience, land tenure status, membership to mutual aid group, consumption and utilization of onion, number of extension contacts and access to credit. Production data such as farm size, hired and family labour used, fertilizer used, seed used, quantity of chemical used, number and nature of work done were also collected. Others are cost of labour and technology used, land clearing, cultivation, planting, weeding, spraying of chemical, fertilizer application and cost of land. Information on output and Market price includes 
output obtained, quantity of output sold and consumed, price received per quantity and market price of onion.

\subsection{Method of Data Analysis}

The study employed descriptive statistics and stochastic production frontier model. Descriptive statistics such as percentages and measures of central tendency (Range, Mean and Frequency distribution) were used to identify and describe socio-economic characteristics of onion farmers.

Stochastic production frontier model

The stochastic production frontier model was used to estimate the efficiencies and factors influencing inefficiency in onion production in the study area.

The linear form of stochastic model that was specified as

$\operatorname{In} \mathrm{Yi}=\beta_{\mathrm{o}}+\beta_{1} \operatorname{In} \mathrm{X}_{\mathrm{i}}+\beta_{2} \operatorname{InX} 2+\beta_{3} \operatorname{In} X_{3}+\beta_{4} \operatorname{In} \mathrm{X}_{4}+\beta_{5} \operatorname{In} \mathrm{X}_{5}+\beta_{6} \operatorname{InX}_{6}+\mathrm{V}-\mathrm{U}$

Where,

The output $\left(\mathrm{Y}_{\mathrm{i}}\right)$ here is the total output in kilogramme.

$\beta_{\mathrm{o}}=$ constant term

$\beta_{1}-\beta_{6}=$ regression coefficient

$\mathrm{X}_{1}=-$ Farm size (Hectares)

$\mathrm{X}_{2}=$ Family labour used in production (Mandays)

$\mathrm{X}_{3}=$ Hired labour used in production (Mandays)

$\mathrm{X}_{4}=$ Seed $(\mathrm{Kg})$

$\mathrm{X}_{5}=$ Fertilizer $(\mathrm{Kg})$

$\mathrm{X}_{6}=$ Chemical (litre)

$\mathrm{V}_{\mathrm{i}}=$ random variability in the cost of production that cannot be influenced by the farmer,

$\mathrm{u}_{\mathrm{i}}=$ the deviation from cost frontier attributable to allocative inefficiency.

The inefficiency of production was modelled in terms of the factors that are assumed to affect the efficiency of production of the farmers. Such factors are related to the socio-economic variables of the farmers. The determinants of technical and allocative inefficiency, $\left(\mu_{i}\right)$, is defined by

$\mu_{\mathrm{i}}=\mathrm{f}\left(\mathrm{Z}_{\mathrm{i}} ; \delta\right)$

Where

$\mu_{\mathrm{i}}=$ technical inefficiency

$Z_{\mathrm{i}}=$ vector of farmer's specific factors

$\delta=$ vector of parameters to be estimated

$\mu_{\mathrm{i}}=\delta_{\mathrm{o}}+\delta_{\mathrm{i}} \operatorname{In} Z_{\mathrm{i}}+\delta 2$ In $Z_{2}+\delta_{3}$ In $Z_{3}+\delta_{4}$ In $Z_{4}+\delta_{5}$ In $Z_{5}+\delta_{6}$ In $Z_{6}+\delta_{7}$ In $Z_{7} Z_{1}=$ age of farmers (years)

$\mathrm{Z}_{2}=$ farming experience in onion production (years)

$\mathrm{Z}_{3}=$ years of formal education (years)

$\mathrm{Z}_{4}=$ extension visits in the cropping season (number)

$Z_{5}=$ household size (number)

$Z_{6}=$ membership of association (years of membership)

$\mathrm{Z}_{7}=$ access to credit (Naira)

The technical efficiency of an individual farm is defined in terms of the ratio of the observed output (Yi) to the corresponding frontier output ( $\left.\mathrm{Yi}^{*}\right)$, given the available technology, conditional on the level of input used by the farm. Hence the technical efficiency of farm ${ }_{i}$ is expressed as follows:

Technical efficiency $=Y i / Y i^{*}=f(X i, \beta) \exp (V i-U i) / f(X i, \beta) \exp (V i)=\exp \left(-U_{i}\right)$. This is obtained from the result of the FRONTIER 4.1 (Coelli, 2000). Based on the individual farm's technical efficiency, the mean technical efficiency for the sample is obtained (Yao and Liu, 2000).

\section{Results and Discussion}

\subsection{Socio-economic characteristics of onion farmers in the study area}

This section describes the results of socio-economic characteristics of the farmers in line with their perceived effect on production decision and efficiency. The variables considered include: age, household size, farm size, years of farming experience, educational level, membership of cooperative association, extension contact, access to credit and marital status.

Age of farmer is an important variable in explaining their behaviour and action with regards to production decision making process. The results presented in Table 1 showed that about $18 \%$ and $24 \%$ of irrigated and rainfed onion famers respectively were within $21-30$ years. Those that were within $31-40$ years constitute $37 \%$ and $45 \%$ for irrigated and rain-fed farmers respectively. The average ages were 40 and 38 years for irrigated and rain-fed farmers. These results imply that onion farmers in the study area were young farmers still in their active productive age group, which private and government agents can effectively use for mass onion production. About $90 \%$ of irrigated farmers and $82.9 \%$ of rain-fed onion farmers were married. $10.4 \%$ of irrigated farmers and $17.1 \%$ of rain-fed onion farmers were single. The average household size for the two groups was 5 members 
per household.

Farming experience will also affect the way a farmer takes decision with regards to resource use and other production decision. As shown in Table 1, 38.7\% of irrigated onion farmers had between 1-10 years of farming experience, $48.1 \%$ had $11-20$ years and $11.3 \%$ had $21-30$ years of farming experience. On the order hand majority $(57.7 \%)$ of rain-fed farmers had farming experience between $11-20$ years, about $39 \%$ had $1-10$ years of experience in onion production. The average farming experience for irrigated and rain-fed farmers were 14 and 13 years respectively.

Education is very important in gauging the ability of farmers to take some vital decision on the adoption of innovation, use of credit and the size of production outfit to engage in. The results also indicate that $13.2 \%$ of irrigated farmers had Qu'ranic education, $28.3 \%$ had primary education, and 36.8\% had secondary education. Those that had tertiary education constitute 19.7\%. Among the rain-fed farmers 19.8\% had Qu'ranic education, $27.9 \%$ had primary education, $36 \%$ had secondary education. Only $16.2 \%$ had tertiary education. These results showed that onion farmers in the study area had one form of formal education or the other. These results implied that level of awareness and adoption of agricultural innovations among onion farmers could be high.

Farm size is an important production variable as this will determine the level of resources to be committed into production such as fertilizer, seed, labour and so on. More than half $(53.45 \%)$ of irrigated farmers had farm size of between 0.1-1.0 hectares and 23.27\% had between 1.1-2.0 hectare. Among the rain-fed farmers majority $(59.46 \%)$ had farm size between 0.1-1.0 hectares. The average farm size among irrigated and rain-fed farmers was 1.74 hectares and 1.44 hectares respectively. The difference in the mean farm size for both irrigated and rain-fed onion farmers could be attributed to large irrigable land which is suitable for the growing of onion, while rain-fed farmers had to share his land among other crops with onion during rainy season.

Extension contact and interaction has been found to be of significant importance to farmers as it affords them opportunity to get access to useful innovation that can help them improve their productivity. This study further revealed that majority of irrigated $(68.9 \%)$ and rain-fed $(73 \%)$ farmers do not have access to extension contact in the study area. It was found that only about $18 \%$ of the farmers had access to extension agents once in a year. This imply that only about one-third of onion farmers in the study area had access to extension agents, who are the main source of farmers' information on improved agricultural technologies.

Access to credit is important as it affords farmers the opportunities for the uptake of available technologies as money are needed to purchase new inputs like fertilizers, agrochemicals and improved seeds. The results revealed that majority of irrigated $(86.79 \%)$ and rain-fed $(73.9 \%)$ farmers did not have access to credit. About $10 \%$ of irrigated farmers received between $\$ 1,000$ - $\$ 10,000$ only $2.83 \%$ received more than $\$ 10,000$. Among rain-fed farmers, $18.92 \%$ received between $\$ 1,000$ and $\$ 10,000$ while about $10 \%$ received above $\$ 10,000$. This implied that more than three-quarter of onion farmers do not have access to credit, and the amount given to few onion farmers is usually very small to allow for meaningful production exercise. On the other hand, onion farmers may resort to local money lenders whose credits are usually at cut throat interest rate which may not encourage sustainable production process. Membership of a cooperative enables farmers to interact with other farmers, share their experiences and assist themselves. Interaction of farmers with other farmers is an avenue through which innovation diffusion can occur. The result implied that $90 \%$ of onion farmers cannot benefit from government subsidy programme on farm inputs, which is usually channeled through farmers' cooperative societies as only very few percentage of these farmers are cooperators that have just been members for between 2 and 3 years for irrigated and rain-fed farmers respectively. 
Table 1: Socioeconomic characteristics of onion farmers

\begin{tabular}{|c|c|c|}
\hline Socioeconomic characteristics & Irrigated & Rain-fed \\
\hline \multicolumn{3}{|l|}{ Age (Years) } \\
\hline $21-30$ & $19(17.9)$ & $27(24.3)$ \\
\hline $31-40$ & $39(36.8)$ & $50(45.0)$ \\
\hline $41-50$ & $31(29.2)$ & $23(20.7)$ \\
\hline $51-60$ & $13(12.3)$ & $11(9.9)$ \\
\hline $61-70$ & $4(3.8)$ & Nil \\
\hline Mean & 40 & 38 \\
\hline \multicolumn{3}{|l|}{ Marital status } \\
\hline Married & $95(89.6)$ & $92(82.9)$ \\
\hline Single & $11(10.4)$ & $19(17.1)$ \\
\hline \multicolumn{3}{|l|}{ Household size } \\
\hline $1-5$ & $66(62.3)$ & $65(58.6)$ \\
\hline $6-10$ & $35(33.0)$ & $40(36.0)$ \\
\hline $11-15$ & $3(2.8)$ & $4(3.6)$ \\
\hline $16-20$ & $2(1.9)$ & $2(1.8)$ \\
\hline Mean & 5 & 5 \\
\hline \multicolumn{3}{|l|}{ Farming experience } \\
\hline $1-10$ & $41(38.7)$ & $43(38.7)$ \\
\hline $11-20$ & $51(48.1)$ & $64(57.7)$ \\
\hline $21-30$ & $12(11.3)$ & $3(2.7)$ \\
\hline $31-40$ & $2(1.9)$ & $1(0.9)$ \\
\hline Mean & 14 & 13 \\
\hline \multicolumn{3}{|l|}{ Education } \\
\hline Qu'ranic education & $14(13.2)$ & $22(19.8)$ \\
\hline Primary education & $30(28.3)$ & $31(27.9)$ \\
\hline Secondary education & $39(36.8)$ & $40(36.0)$ \\
\hline Tertiary education & $23(19.7)$ & $18(16.2)$ \\
\hline \multicolumn{3}{|l|}{ Farm size } \\
\hline $0.1-1.0$ & $62(53.45)$ & $66(59.46)$ \\
\hline $1.1-2.0$ & $27(23.27)$ & $30(27.03)$ \\
\hline $2.1-3.0$ & $18(15.52)$ & $11(9.91)$ \\
\hline $3.1-4.0$ & $5(4.31)$ & $3(2.70)$ \\
\hline Greater than 4.0 & $12(3.45)$ & $1(0.90)$ \\
\hline Mean & 1.74 & 1.44 \\
\hline \multicolumn{3}{|l|}{ Extension contact } \\
\hline No contact & $73(68.9)$ & $81(73.0)$ \\
\hline Once a year & $20(18.9)$ & 21(18.9) \\
\hline Twice a year & $11(10.3)$ & $9(8.1)$ \\
\hline Four times a year & $2(1.9)$ & Nil \\
\hline \multicolumn{3}{|l|}{ Amount of credit received( } \\
\hline 0 & $92(86.38)$ & $82(73.9)$ \\
\hline $1,000-10,000$ & $11(10.38)$ & $21(18.92)$ \\
\hline $10,000-20,000$ & $3(2.83)$ & $8(7.21)$ \\
\hline Greater than 20,000 & Nil & $3(2.71)$ \\
\hline Mean & $\$ 9100$ & $¥ 16200$ \\
\hline \multicolumn{3}{|c|}{ Years of membership of association } \\
\hline No membership & $86(81.13)$ & $99(89.2)$ \\
\hline $1-5$ & $6(5.66)$ & $7(6.30)$ \\
\hline $6-10$ & $11(10.38)$ & $5(4.50)$ \\
\hline $10-15$ & $3(2.83)$ & Nil \\
\hline Mean & 2 & 3 \\
\hline
\end{tabular}

Figures in parentheses are percentages

\subsection{Input-Output Relationship in Onion Production}

The result of Maximum Likelihood Estimates (MLE) from the production frontier is presented in Table 2. The estimated parameters of sigma-squared were 3.319 and 8.193 for irrigated and rain-fed onion production systems respectively. These values were significantly different from zero at $5 \%$ level of probability, indicating a good fit 
and the correctness of the specified distributional assumption of the composite error term. The generalized likelihood ratio statistics were 32.214 and 81.44 for irrigated and rain-fed respectively. This ratio exceeds the critical chi-square values at $1 \%$ level of significance. The log likelihood ratio value represents the value that maximizes the joint densities in the estimated model. Thus, the functional form that is, Cobb-Douglas used in this estimation is an adequate representation of the data. The values of the gamma statistics 0.929 and 0.988 for irrigated and rain-fed respectively are attributable to farmers' inefficiency factors. The result revealed that technical inefficiency effects were present in onion production under the two production systems in the study area.

The estimated coefficient for farm size for irrigated (0.851) and rain-fed (0.006) were positive and statistically significant at $1 \%$ level of probability. This implies that as more land is being put to onion production the output level will increase. Onion production in the area is subsistent and traditional in nature; therefore access to land would determine the level of onion output. The results also implied that a unit increase in land size would increase irrigated and rain-fed onion output by 0.851 and 0.006 units respectively. This further implied that there is the possibility of increasing onion yield when more land is put into its production.

The estimated parameter of hired labour for irrigated (0.417) was positive and significant at $10 \%$ while under rain-fed system the coefficient for hired labour $(0.113)$ was positive and significant at $1 \%$. These show that hired labour exerts positive and significant influence on onion output under irrigated and rainfed system of production. The implication of this is that onion output would increase if onion farmers in the study area increase the use of hired labour. The results also implied that a unit increase in the amount of hired labour would increase irrigated and rain-fed onion output by 0.417 and 0.113 units respectively.

As shown in Table 2, coefficient of family labour for irrigated $(0.548)$ and $(0.075)$ for rain-fed were positive and significant at 1 percent level. These imply that family labour is an important input in onion production in the study area and the output would increase with increase in the use of family labour. The Coefficient $(0.530)$ of seed for irrigated onion and 0.481 for rain-fed onion were positive and significant at $1 \%$ level. This implies that increase in the use of seed will lead to an increase in yield. The coefficient $(0.234)$ of fertilizer was not significant under rain-fed system; this can be attributed to wrong timing of application, type and method of application by rain-fed onion farmers. However, for irrigated system, the coefficient (0.595) was positive and significant at $1 \%$ level. It showed that fertilizer has significant influence on onion production under irrigated system. These results implied that if fertilizer is increased by $1 \%$, the level of irrigated and rain-fed onion output would increase by 0.595 and 0.234 units respectively. It implied that irrigated onion farmers complied with fertilizer type, time and method of application.

The results further showed that agrochemical was positively related to onion yield under irrigated at $5 \%$ level of significant, while under rain-fed it was negative at $1 \%$ level. The reason for the ineffectiveness of agrochemical on rain-fed onion could be non adherence to specification on mixing formula and wrong time of application. The chemical could be washed away by rain immediately after its application, making it ineffective. The implication of this is high incidence of pest and disease infestation which invariably lead to low yield in rain-fed onion production. 
Table 2: Maximum Likelihood Estimation Results of Stochastic Frontier Production Function

\begin{tabular}{lll}
\hline Variable & Irrigated & Rain-fed \\
\hline Constant $\left(\beta_{0}\right)$ & 5.570 & 4.787 \\
& $(5.289)$ & $\left(170.99^{* * *}\right)$ \\
Farm size $\left(\mathrm{X}_{1}\right)$ & 0.851 & 0.006 \\
& $\left(13.531^{* * *}\right)$ & $\left(6.017^{* * *}\right)$ \\
Hired labour $\left(\mathrm{X}_{2}\right)$ & 0.417 & 0.113 \\
& $\left(1.914^{*}\right)$ & $\left(17.469^{* * *}\right)$ \\
Family labour $\left(\mathrm{X}_{3}\right)$ & 0.548 & 0.075 \\
& $\left(4.531^{* * *}\right)$ & $\left(20.388^{* * *}\right)$ \\
Seed $\left(\mathrm{X}_{4}\right)$ & 0.530 & 0.481 \\
& $\left(7.611^{* * *}\right)$ & $\left(220.22^{* * *}\right)$ \\
Fertilizer $\left(\mathrm{X}_{5}\right)$ & 0.595 & 0.234 \\
& $\left(266.21^{* * *}\right)$ & $(1.503)$ \\
Agro chemicals $\left(\mathrm{X}_{6}\right)$ & 0.327 & -0.178 \\
& $\left(2.082^{* *}\right)$ & $\left(59.635^{* * *}\right)$ \\
Variance Parameters & & 8.913 \\
Sigma squared $\left(\sigma^{2}\right)$ & 3.319 & $\left(2.071^{* *}\right)$ \\
Gamma $(\gamma)$ & $\left(2.895^{* * *}\right)$ & 0.988 \\
LR test & 0.929 & $\left(51.369^{* * *}\right)$ \\
log likelihood function & $\left(30.512^{* * *}\right)$ & 81.44 \\
\hline
\end{tabular}

Figures in parentheses are t-ratio

$\sigma^{2}=\sigma_{\mathrm{v}}^{2}+\sigma_{\mathrm{u}}^{2}, \gamma=\sigma_{\mathrm{u}}^{2} / \sigma^{2}$

\subsection{Technical Efficiency Indices}

The results in Table 3 showed the frequency distribution of technical efficiency. The results reveal that technical efficiency index varied from one farmer to another and ranged from a minimum of 0.24 to a maximum of 0.99 , with a mean of 0.89 and 0.83 for irrigated and rain-fed onion farmers respectively. The maximum efficiency for rain-fed farmers was 0.98 with minimum efficiency of 0.24 . The estimated mean technical efficiency for irrigated onion farmer was 0.89 and for the rain-fed it was 0.83 . As shown in Table 4.16 majority of irrigated onion farmers (66.04\%) and rain-fed farmers (60.36) had efficiency score between $0.9-1.0$. Only $2.83 \%$ of the irrigated farmers and $6.40 \%$ of rain-fed farmers had efficiency scores less than 0.60 . The implication of the results is that the average irrigated onion farmer requires $10 \%$, that is, $\{1-(0.89 / 0.99) \times 100\}$ cost savings to attain the status of the most efficient irrigated onion farmer and $15 \%$, that is, $\{1-(0.83 / 0.98) \times 100\}$ to attain the status of the most efficient rain-fed onion farmer. The least performing irrigated farmer would need $61 \%$ cost savings which is $\{1-(0.38 / 0.99 \times 100\}$ and rain-fed farmer would need $74 \%$ that is $\{1-(0.24 / 0.98 \times 100\}$ to become the most efficient farmer.

The difference in the technical efficiency of irrigated and rain-fed onion farmers could be attributed to the system of production, and difference in the quantity of inputs used by irrigated and rain-fed onion farmers. The fact that the technical efficiencies of all sampled onion farmers are less than 1 implies that no farmer reached the frontier of production. The mean efficiency of irrigated onion farmers implies that the shortfall in the output of onion is $11 \%$ for irrigation farmer while for rain-fed is $14 \%$. Thus, opportunity still exists for increasing farmers' productivity through increasing efficiency in the use of existing resources. It has also demonstrated that irrigated onion production is fairly more efficient than the rain-fed onion in the study area and this could be the nature of onion production in the entire north bearing in mind the similarity in the ecological conditions and farmers' management system. 
Table 3: Frequency Distribution of Technical Efficiency Estimates

\begin{tabular}{lcr}
\hline Technical efficiency range & Irrigated & Rain-fed \\
\hline $0.21-0.30$ & Nil & $1(1.90)$ \\
$0.31-0.40$ & $1(0.94)$ & Nil \\
$0.41-0.50$ & Nil & $1(0.90)$ \\
$0.51-0.60$ & $2(1.89)$ & $4(3.60)$ \\
$0.61-0.70$ & $6(5.66)$ & $5(4.50)$ \\
$0.71-0.80$ & $8(7.55)$ & $13(11.71)$ \\
$0.81-0.90$ & $19(17.92)$ & $20(18.02)$ \\
$0.91-1.0$ & $70(66.04)$ & $67(60.36)$ \\
Total & $106(100)$ & $111(100)$ \\
Mean & 0.89 & 0.83 \\
Minimum & 0.38 & 0.24 \\
Maximum & 0.99 & 0.98 \\
\hline
\end{tabular}

Figures in parentheses are percentages

\subsection{Determinants of technical inefficiency}

The results in Table 4 showed the determinants of technical inefficiency in irrigated and rain-fed onion production in Kano State. It was revealed that ages of the farmers were positive and significant at $10 \%$ for irrigated farmers while it was also positive and significant at $5 \%$ for rain-fed farmers. These imply that as the age of farmer increases technical inefficiency also increases. This may be due to the fact that the older the farmer, the less the willingness to take risk and try innovation that may increase onion output. Also older farmers are less receptive to innovation unlike younger farmers.

Years of education showed a negative relation with technical inefficiency and are significant at $5 \%$ level for the two groups of onion farmers. The negative coefficient of education reveals that a high level of education results in a reduction in technical inefficiency of onion farmers. Anon (2006) noted that education is one of the socio - economic variable that greatly affects farmers' decision to accept and adopt modern farm technologies. Also, Kalirajan and Shard (2004) observed that education sharpens managerial input and leads to a better assessment of the importance and complexities of good decisions in farming. It also implied that education widens the scope of farmers' horizon towards adoption of new technological innovation, thereby moving him away from traditional practices to adopt technological concepts.

Experience in onion production was negative and significant at 5 percent for irrigated farmers. This shows that increase in experience in irrigated onion production would reduce technical inefficiency. Farmers' experience could be associated with skill accumulation which could enhance productivity and resource allocations thereby reduce technical inefficiency. It is positive and not significant for rainfed onion farmers, this implies that experience has no significant effect on technical inefficiency, i.e, increase in experience would not reduce their technical inefficiency. This can be attributed to strict adherence to old traditional practices of onion production.

Household size showed a negative relation with predicted technical inefficiency and is significant at $5 \%$ level for rain-fed onion farmers. The implication of this is that rain-fed onion farmers whose household size is $35 \%$ more than irrigated onion farmers are technically efficient. This may be due to farmers access to family labour because as the number of people in a household increases, a pool of family labour becomes available and this could lead to specialization.

Membership of cooperative was negative and significant at $10 \%$ level of significant for irrigated onion farmers. The negative coefficient for membership imply that membership of association reduces technical inefficiency in irrigated onion production. Membership of association could affords the farmers the opportunity of sharing information on modern farming practices by interacting with other farmers. Okike (2000) noted that the reduction of inefficiency effects through farmers belonging to cooperatives is linked to cooperatives being a source of good quality inputs, information and organized marketing of products. This implied that irrigated onion farmers can market their produce through cooperative societies for higher profit and income.

Furthermore, farmer accessibility to credit was negative and significant at $5 \%$ for irrigated onion farmers and this implies that access to credit facility was found to reduce technical inefficiency. This suggests that availability of credit is an important factor for attaining a higher level of technical efficiency. Farmers who are technically inefficient can possibly be more efficient by having access to credit because credit facility may ease 
the timely acquisition of inputs, thus reducing the inefficiency level of the farmers. Extension contact is positive and not significant to both irrigated and rainfed farmers in the area, this implies that extension contact has no effect on their technical inefficiency. This could be attributed to either wrong extension package or lack of constant extension visit to onion farmers in the area. This implied that extension services are not extended or not adequate to onion producers in the study area.

Table 4: Socio-economic factors influencing technical inefficiency

\begin{tabular}{lll}
\hline Variable & Irrigated & Rain-fed \\
\hline Constant & 2.595 & 2.209 \\
& $(1.106)$ & $(0.979)$ \\
Age & 0.113 & 0.309 \\
& $\left(1.674^{*}\right)$ & $\left(2.486^{* *}\right)$ \\
Education & -0.175 & -0.432 \\
& $\left(-2.142^{* *}\right)$ & $\left(-1.934^{* *}\right)$ \\
Experience & -0.249 & 2.704 \\
Household size & $\left(-1.973^{* *}\right)$ & $\left(1.614^{*}\right)$ \\
& -0.071 & -1.170 \\
Extension contact & $(-0.620)$ & $\left(-2.213^{* *}\right)$ \\
& 0.771 & 1.374 \\
Cooperative & $(1.364)$ & -0.300 \\
& -0.734 & $(-1.475)$ \\
Access to credit & $\left(-1.648^{*}\right)$ & 0.246 \\
& -0.222 & $(1.062)$ \\
\hline
\end{tabular}

Figures in parentheses are t-ratio

\section{Conclusion and Recommendations}

The socio-economic characteristics of onion farmers in the study area revealed that, married educated youth with an average of 18 years farming experience are involved in both system of onion production on small scale. Estimated mean technical efficiency was 0.89 and 0.83 for irrigated and rain-fed respectively, it is evident here that, the two production systems did not reach the frontier of production and therefore opportunities exists for improvement in resource utilization. Education, farming experience, household size, membership of cooperative and access to credit are major socio-economic determinant of technical efficiency under both system of onion production. In other to raise efficiency level, the study recommends the need for the commitment of nongovernmental organization and government in the provision of inputs such as fertilizer, agrochemicals, seeds and farm implements at affordable rates. The guaranteed minimum price support policy of government should include Horticultural crops especially onion in the policy framework. This policy is aimed at establishing farmers produce price throughout the year by fixing prices for agricultural produce. This would enhance their level of income

\section{References}

Battese, G. E. and Corra G.S., (2001). Estimation of a Production Frontier Model; with Application to the Pastoral Zone of Eastern Australia. Australia Journal of Agricultural Economics, 2(1);167-179.

Belbase, K and Grabowski, R (2000).Technical Efficiency in Nepalese Agriculture. Journal of Development Agriculture.1(6):515-525

Brice, J., Currah, L., Malins, A. and Bancroft, R. (1999). Onion storage in the tropics. A practical guide to methods of storage and their selection. Oxford University Press, London. Pp 99-107

Currah, L. and Proctor, F. J. (2000). Onions in Tropical Regions. Natural Resources Institute Bulletine No 35.

Denton, E.O. and Ojeifor, T. (2001). Traditional Practices in Onion Production in Ashanti Region of Ghana. Ghana Journal of Agriculture, 1(3):51-79.

FAO (2005). Food and Agriculture Organization of the United Nations. FAOSTAT data, 2005 Annual Report, Rome, Italy. Pp 11-13

Kalirajan, K. And Shard, P. (2004). Methods of Assessing Production. Punjab-Sroh Press, India. Pp 214-219

Mehmet, B. and Ceyhan, V. (2007). Measuring the technical efficiency and exploring the inefficiency determinants of vegetable farms in Kansas Farming. Kansas Journal of Agriculture 3(2) 32-53.

Okeowo, L.J. (2011). Analysis of technical efficiency in some selected vegetable production in Gombe State. Journal of Vocational Education, F.C.E. (T), Gombe, 2(1) 73-93.

Okike, I. (2000). Crop Livestock Interactions and Economic Efficiency of Farmers in the Savannah Zones of Nigeria. Ph. D Thesis, Department of Agricultural Economics, University of Ibadan, pp 155. 
Olofin, D., John, H. P. and Hopekins, T. (2008). Map of Nigeria Showing Vegetation Belt and Irrigation Sites. Macmillan Press. Pp 15-17

Purseglove, J.W. (2001). Tropical crops Monocotyledons. Longman Singapore Publishers, PTC, Ltd. Pp 271279.

Shapiro, J. T. and Muller, P. A. (1999). Improving Efficiency in Agricultural Production. New York Macmillan Press.

Udoh, E.J. (2000). Land Management Resource. Use Efficiency Among Farmers in South Eastern Nigeria. Unpublished Ph.D thesis, Department of Agricultural Economics, University of Ibadan. Pp 87-93

Villano, R. and Fleming, E. (2006). Technical inefficiency and production risk in rice farming: Evidence from central Luzon Philippines, Asian Economic Journal, 20(1): 29 -46.

Yao, S. and Liu, Z. (2008) Determinant of grain production and technical efficiency in China. Journal of Agricultural Economics, 4(9):171-184 